Dr ENA MIRKOVIĆ, istraživač-saradnik

Institut za srpsku kulturu - Priština/Leposavić

Leposavić, Republika Srbija

ena04111986@gmail.com

originalan naučni rad

UDK: 323.1(497.115)"1944/1952"

primljeno: 19. januar 2018.

32:929 Нешковић Б.

prihvaćeno: 16. maj 2018.

https://doi.org/10.29362/ist20veka.2018.2.mir.101-116

\title{
ODNOS BLAGOJA NEŠKOVIĆA PREMA NACIONALNOM PITANJU 1944-1952.*
}

APSTRAKT: U članku se analizira odnos Blagoja Neškovića prema nacionalnom pitanju u posleratnoj Jugoslaviji. Nešković je bio istaknuta ličnost srpskog komunističkog pokreta do 1952, kada je zbog neslaganja sa režimom uklonjen sa političke scene, pri čemu je kao jedan od razloga naveden i odnos prema nacionalnom pitanju. Nastojali smo da istražimo u kojoj meri je zaista zastupao prosrpske interese u Komunističkoj partiji Jugoslavije. Pokazalo se da Blagoje Nešković nije bio pogodna osoba koja bi podržala politiku nacionalnog slabljenja Srbije na uštrb jačanja Jugoslavije. On je bio jedan od smelijih srpskih funkcionera u izražavanju svojih nacionalnih osećanja, a KPJ je pokazala spremnost da se odlučno obračuna sa svima koji su mogli da dovedu u pitanje ispravnost njene politike „,bratstva i jedinstva“.

KLJUČNE REČI: Blagoje Nešković, Srbija, nacionalno pitanje, granice, Komunistička partija Jugoslavije

Blagoje Nešković ${ }^{1}$ je na početku Drugog svetskog rata bio „,novo lice“ komunističkog pokreta; pokazao je spremnost da u ratnim okolnostima disciplinovano izvršava zadatke koje mu je KPJ poveravala, što je i bio jedan od razloga zbog kojih je uspeo da dokaže svoje sposobnosti i stekne dovoljno poverenja da bude imenovan za sekretara Pokrajinskog komiteta (PK) za Srbiju, od kada

\footnotetext{
* Rad je deo projekta Materijalna i duhovna kultura Kosova i Metohije (178028), koji finansira Ministarstvo prosvete, nauke i tehnološkog razvoja Republike Srbije.

${ }^{1}$ Blagoje Nešković (1907-1984), rođen u Kragujevcu, završio je Medicinski fakultet u Beogradu i učestvovao kao borac i lekar u Španskom građanskom ratu. Bio je član Komunističke partije Jugoslavije od 1935. godine. Za vreme Drugog svetskog rata izabran je za sekretara Pokrajinskog komiteta KPJ za Srbiju. Posle oslobođenja bio je sekretar Centralnog komiteta Komunističke partije Srbije i predsednik vlade NR Srbije do 1948. godine. Godine 1952. postao je potpredsednik jugoslovenske vlade, ali je ubrzo pod optužbom sprovođenja oportunističke politike i saradnje sa Informbiroom primoran na ostavku na sve partijske funkcije i isključen iz Centralnog komiteta SKJ. Od tada se posvećuje naučnoj karijeri i ne učestvuje u političkom životu. SK Srbije je 1984. odbio njegov zahtev za rehabilitaciju.
} 
počinje njegov politički uspon. ${ }^{2}$ Najveći deo rata proveo je u Beogradu, do 1943. godine kada je izašao na slobodnu teritoriju. ${ }^{3}$

Stavovi Blagoja Neškovića o položaju Srbije u novom komunističkom poretku, kao i njegovo nacionalno osećanje, počeli su da izbijaju na površinu u periodu njegovog boravka van Srbije tokom 1943-1944, najpre kada se postavilo pitanje osnivanja Komunističke partije Srbije. To je prvi put bilo pomenuto na sastanku Politbiroa CK KPJ u Jajcu održanom 16-18. oktobra 1943. godine. ${ }^{4}$ Inicijativa je potekla iz Srbije, jer ona jedina nije imala svoju KP. Komunističke partije Hrvatske i Slovenije su osnovane u međuratnom periodu dok se smatralo da „radne mase Srbije ne traže stvaranje KP Srbije“, jer „srpski narod nije nacionalno ugnjeten. Srbi su vladajuća nacija i ne osećaju nacionalno ugnjetavanje s strane druge narodnosti. Prema tome ni klasna borba ne zauzima odlike borbe za nacionalno oslobođenje. “5 Blagoje Nešković je 16. jula 1944. još jednom predložio što skorije osnivanje Komunističke partije Srbije, navodeći da bi se na taj način stalo na put „neprijateljskim elementima“ koji koriste nepostojanje KP Srbije kao argument protiv Partije. ${ }^{6}$ Međutim, Josip Broz Tito je 22. jula 1944. odbio ovaj predlog, smatrajući da još uvek ne postoje adekvatni uslovi za to sve dok ne dođe do oslobođenja i slamanja ,reakcije“ u Srbiji. ${ }^{7}$

Iako je privremeno odustao od pitanja formiranja KP Srbije, Blagoje Nešković je pokazao da će braniti srpske interese i kada se bude pokrenulo pitanje budućih granica nove države. Avgusta 1944, u manastiru Prohor Pčinjski, konstituisano je Antifašističko sobranje narodnog oslobođenja Makedonije (ASNOM) kao najviše zakonodavno i izvršno telo makedonske države. Pitanje razgraničenja sa budućom republikom Makedonijom pokrenuto je kada je KP Makedonije postavila pitanje Preševa u pismu CK KPJ od 26. avgusta 1944: „PK je tražio Preševo pod svoje rukovodstvo, a treba da bude pod našim, s obzirom da je do sada stalno bilo naše i što ekonomski gravitira ka jugu. “8 Blagoje Nešković se kao sekretar PK usprotivio i pretenzijama KP Makedonije na prostor Pčinje. ${ }^{9}$ On u pismu CK KPJ od 6. septembra 1944. navodi: „Makedonci su vrlo uski i nepravedni. Teritoriju Pčinje, gde živi isključivo srpski živalj s starim borbenim tradicijama, smatraju Ristovačkom Makedonijom, čak su i svoje sobranje izabrali na teritoriji Pčinje, u kako oni kažu, istorijskom manastiru sve-

\footnotetext{
${ }^{2}$ Istorijski arhiv Beograda (IAB), fond 2157. Legat Blagoja Neškovića i Branislave Brane Perović, kutije 1-32, 2157-8-1.

${ }^{3}$ Isto, 2157-8.

${ }^{4}$ Đorđe O. Piljević, ,Savetovanje Politbiroa CK KPJ na Visu i stvaranje KP Srbije“, u: Osnivački kongres Komunističke partije Srbije: zbornik radova, urednik Aleksandar Kasaš (Beograd: Zavod za udžbenike i nastavna sredstva, 1988), 41; Branko Petranović, Istorija Jugoslavije 1918 1988, II (Beograd: Nolit, 1988), 33.

5 „O stvaranju K. P. Hrvatske i K. P. Slovenije“, Proleter, 7/8, (1935), 396.

${ }^{6}$ Izvori za istoriju SKJ. Dokumenti centralnih organa KPJ. NOR i revolucija 1941-1945, knjiga 18, priredio Milovan Dželebdžić (Beograd: Izdavački centar „Komunist“, 1986), 288.

${ }^{7}$ Isto, 333.

${ }^{8}$ Венцеслав Глишић, Досије о Благоју Нешковићу: прилози за биографију (Београд: Службени гласник, 2011), 68.

${ }^{9}$ B. Petranović, Istorija Jugoslavije 1918-1988, II, 303.
} 
ti Prohor Pčinjski. Mi nećemo dozvoliti nikakve rasprave sa Makedoncima oko granica i smatramo da je glavno da su se digli u borbu, za ostalo ćemo lako. Smetnje koje oni nama čine svojom uskogrudošću oko pitanja granica mi ćemo lako otkloniti ne upuštajući se uopšte u raspravljanje oko granica“. ${ }^{10}$ Josip Broz je predlagao da se pitanje granice ostavi za kasnije, jer prvo treba ,isterati Bugare, Nemce i domaće izdajnike" tako da su ova pitanja zbog nezavršenog oružanog sukoba ostala da sačekaju period oslobođenja.

Blagoje Nešković je pokazao i otvoreno neslaganje sa zvaničnom politikom KPJ u okružnici od 1. septembra 1944. pod nazivom „Svim partijskim organizacijama u Srbiji“, koja je naglašavala ulogu Srbije i zaslugu prvenstveno srpskih komunista $\mathrm{u}$ toku rata $\mathrm{i}$ u samom jugoslovenskom komunističkom pokretu, ističući da je srpski narod imao naprednu predvodničku ulogu među ostalim narodima Jugoslavije. ${ }^{11}$ Prihvatajući odluke Drugog zasedanja AVNOJa srpski komunisti, sa Blagojem Neškovićem na čelu, istakli su da se na taj način obezbeđuje ,veliki značaj Srbije kao federativne jedinice u demokratskoj federativnoj Jugoslaviji“ kao i ,jedinstvo naroda Srbije“. ${ }^{2}$ Okružnica je predstavljala presedan: u njoj su kritikovani oni koji ne uviđaju značaj Srbije i srpskog naroda u rešavanju budućnosti ostalih naroda Jugoslavije, jer se javila još veća „,potreba isticanja značaja Srbije u opštoj borbi u Jugoslaviji, baš Srbije kao federativne jedinice u demokratskoj federativnoj Jugoslaviji jer Srbi ne žive samo u Srbiji“. ${ }^{13}$ To je ujedno bio i prvi put da je Blagoje Nešković tako jasno izrekao svoj stav i o ulozi srpskih komunista u komunističkom pokretu Jugoslavije.

Ovakva okružnica sigurno je izazvala burne reakcije u vrhu KPJ, koja je insistirala da se tekst okružnice mora promeniti i na tome da je pogrešno tvrditi da „srpski narod igra nekakvu vodeću ulogu u rešavanju budućnosti ostalih naroda Jugoslavije [...] To, međutim, nije tačno. I može kod mnogih izazvati pogrešnu predstavu o tome kako srpski narod oslobađanjem drugih naroda treba da stekne i neku veću, vodeću ulogu. Pravilno je reći da se srpski narod može osloboditi samo u zajedničkoj borbi s ostalim narodima Jugoslavije i da u toj zajedničkoj borbi ne može doći do svoje vlastite slobode ako ne uništi razne velikosrpske hegemonističke klike.“" ${ }^{\text {"14 }}$ Pismo je upućeno 17. septembra 1944. i prvobitno ga je potpisao Aleksandar Ranković, a kasnije ga je autorizovao Josip Broz koji je tvrdio da je ono delo celokupnog Politbiroa CK KPJ. ${ }^{15}$ Pismo je bilo prepuno fraza o ,reakcionarnoj Srbiji“, „,srpskom hegemonizmu“, ,,velikosrpskom šovinizmu“, koji je postojao i u redovima same srpske partijske organizacije, koja je trebalo da prihvati te ocene pre nego što bude osnovana KP Srbije, kao i da se odrekne shvatanja da je njena uloga u revoluciji bila presudna. KPJ nije bila spremna da prizna ključnu ulogu koju su srpski komunisti odi-

\footnotetext{
${ }^{10}$ В. Глишић, н. д., 68.

11 Коста Николић, Мит о партизанском југословенству (Београд: Завод за уџбенике, 2015), 403.

${ }^{12}$ Izvori za istoriju SKJ. NOR i revolucija, knjiga 19, 416.

${ }^{13}$ Isto, 419.

${ }^{14}$ Isto, 412.

${ }^{15}$ К. Николић, Мит о партизанском југословенству, 404.
} 
grali na početku rata, iako je ona bila neosporna. Ovo je rezultiralo zabranom 19. septembra 1944. daljeg umnožavanja i distribuiranja okružnice PK KPJ za Srbiju od 1. septembra. Blagoje Nešković je morao da se povuče, pa je istoga dana pokajnički odgovorio da to nije bila konačna verzija okružnice, a s druge strane izvestio je i o vrlo slabom stanju KPJ u mnogim mestima u Srbiji. ${ }^{16} \mathrm{U}$ želji da ublaži reakciju koju je okružnica izazvala on u pismu ističe lošu situaciju u pojedinim mestima u Srbiji i pita se ,kakva će to narodnooslobodilačka vlast, komande mesta i područja biti sutra u oslobođenom, na primer Kraljevu, kad nemamo ni jednog meštanina člana Partije koji će se staviti na čelo tih organa vlasti i vojske, koji treba da okupe sve ostale ljude oko sebe. Ispalo bi tako da se u te organe vraćaju nepouzdani, čak i neprijateljski elementi“. ${ }^{17}$

Posle završetka Drugog svetskog rata i formiranja vlade DFJ nametnulo se pitanje federacije sa ,bratskim državama“ s jedne strane i pitanje granica države sa susedima s druge. Srbiji je bila nametnuta krivica zbog pokreta generala Dragoljuba Mihailovića i od nje se očekivalo da iskupi taj greh i pruži najveći doprinos u okupljanju ,bratskih naroda“. ${ }^{18} \mathrm{Na}$ sednici Izvršnog odbora Narodnog fronta Srbije, održanoj 11. oktobra 1946. u Beogradu, otvorila se diskusija povodom predstojećih izbora i oko toga da li se treba obratiti ,srpskom narodu“, za šta se Blagoje Nešković zalagao, ili narodu Srbije kako se ne bi uvredile ostale nacionalnosti. On je tom prilikom čvrsto ostao pri stavu da je ,osnova srpskog naroda u Srbiji. Srpski narod je u Srbiji, ne u Hrvatskoj i ne znam gde. Ja mislim da bi trebalo prikazati i označiti za samu republiku Srbiju, za srpski narod taj individualitet republike $\mathrm{i}$ to bi moglo s jednim pasusom da uđe $\mathrm{i}$ da se vrlo koncizno kaže“. ${ }^{19}$

Posle rata pitanja razgraničenja je neminovno moralo ponovo doći na red. Sporove oko razgraničenja nova država je imala skoro sa svim susedima. $\mathrm{Na}$ severozapadu se otvorilo sporno pitanje Trsta, Istre i Slovenačkog primorja tzv. Julijske Krajine. Prema sporazumu potpisanom u Beogradu od 9. maja 1945. jedan deo Julijske Krajine, koji je uključivao Trst, železničke pruge i puteve prema Austriji (preko Gorice, Kobarida i Trbiža) i zapadni deo Istre sa Pulom, trebalo je da bude pod savezničkom vrhovnom komandom. ${ }^{20}$ Kada su se povukle trupe Jugoslovenske armije, 12. juna 1945. godine, teritorija Julijske Krajine je podeljena na zonu ,A“ pod vojnom upravom zapadnih saveznika i na zonu „B“" sa jugoslovenskom vojnom upravom. ${ }^{21}$ Jugoslavija se nije mirila sa odstupanjem iz Trsta i Pule, smatrajući da ima zaslužene pretenzije na te gradove. Blagoje Nešković je podržavao stav jugoslovenske vlade po pitanju Julijske

\footnotetext{
${ }^{16}$ Исто, 407.

${ }^{17}$ Izvori za istoriju SKJ. NOR i revolucija, knjiga 19, 511.

18 Бранко Петрановић, Југословенско искуство српске наџионалне интеграције (Београд: Службени лист СРЈ, 1993), 106.

19 Arhiv Srbije (AS), fond G-17, Predsedništvo vlade Narodne republike Srbije (1945-1953), Sednica izvršnog odbora Narodnog fronta Srbije.

${ }^{20}$ Isto.

${ }^{21}$ Bojan Dimitrijević i Dragan Bogetić, Tršćanska kriza 1945-1954 (Beograd: Institut za savremenu istoriju, 2009), 21.
} 
Krajine, ocenjujući da ona treba da bude priključena FNRJ: „, Mi možemo pretrpeti nepravdu, kao što je slučaj sa Trstom i Julijskom krajinom, gde nam Englezi i Amerikanci isto tako i naši stari saveznici Francuzi ne pružaju pomoć koju smo zaslužili. Sada ćemo videti rezultate na Mirovnoj konferenciji u Parizu i nema sumnje da će naša Savezna vlada tražiti i mi svi treba neprestano da tražimo da se sprovede pravda u pogledu Trsta i Julijske Krajine, naime, da se Trst i Julijska Krajina priključe našoj zemlji““. ${ }^{22}$

Na Mirovnoj konferenciji u Parizu zapadne sile su se suprotstavile jugoslovenskom zahtevu za reviziju severozapadnih granica. Velika Britanija i SAD su favorizovale Italiju dok je sovjetska delegacija predlagala da Jugoslaviji pripadnu Istra, Trst, Gorica i druga slovenačka naselja. ${ }^{23}$

Februara 1947. potpisani su mirovni ugovori sa Italijom, Rumunijom, Finskom, Mađarskom i Bugarskom. Mađarska je morala da plati reparacije u iznosu od 50 miliona dolara, a granice su vraćene na stanje od 1. januara 1938. godine. ${ }^{24}$ Jugoslavija je imala pretenzije na deo oko Bajskog trougla i teritorije Pečuja i Arada na kojima je bio nastanjen određeni broj Jugoslovena, a što je i Josip Broz Tito istakao komandantima Crvene armije: „Najveći deo naših sunarodnjaka naseljen je u oblasti Bajskog trokuta, Pečuja i Arada, a ima ih rasturenih duž cele jugoslovensko-mađarske granice. Mi ćemo na međunarodnoj konferenciji tražiti da se te oblasti prisajedine našoj državnoj teritoriji, jer na to imamo $\mathrm{i}$ istorijsko pravo. “25 Jugoslavija je, međutim, odustala od ovih zahteva $\mathrm{i}$ na Mirovnoj konferenciji Edvard Kardelj je tražio samo manje korekcije postojeće granice. Privremena vlada DFJ je pristala da odustane od traženja revizija granica i pripajanja teritorije oko Bajskog trougla, ukoliko mađarska vlada prizna autonomna prava manjinama koje tu žive.

U Ministarstvu za kolonizaciju DFJ (ministar Sreten Vukosavljević), javila se ideja da se Mađari nastanjeni u pograničnim srezovima (bačkotopolski, senćanski, somborski, starobečejski), isele u Mađarsku, a da se 20.000 Hrvata i 6.500 Srba iz Mađarske na osnovu te razmene vrate u zemlju. Time bi se ostvarila veća etnička homogenost u pograničnim srezovima, a i olakšao proces agrarne reforme (bezemljaši mađarskog porekla kojih je bilo oko 100.000 više ne bi bili zainteresovani za podelu zemlje). ${ }^{26}$ Blagoje Nešković se takođe zalagao za ovo rešenje: „Mi u rukovodstvu Srbije bili smo za to da se iz Vojvodine proteraju Mađari u Mađarsku, a da se Srbi iz Mađarske nasele u Vojvodini, kao što smo uradili sa Nemcima. Radi toga su tada u Beograd došli Rakoši i Farkaš i razgovarali sa Brozom. Kad mi je Broz rekao da ne treba proterivati Mađare iz Vojvodine, ja sam protiv toga protestovao kod Broza odmah pošto mi je to saopštio. Sve su ovo bili povodi da protiv mene budu Broz i ljudi oko njega, opet

\footnotetext{
${ }^{22}$ AS, G-18, fond Narodna skupština Narodne republike Srbije (NRS), Prepis govora predsednika vlade, 94.

${ }^{23} \mathrm{~B}$. Petranović, Istorija Jugoslavije, III, 164.

${ }^{24}$ Isto, 173.

${ }^{25}$ Isto.

${ }^{26}$ Isto, 176.
} 
bez ikakvog razloga“' ${ }^{27} \mathrm{U}$ istom ministarstvu postojali su predlozi da se jedan broj srezova u severnoj Bačkoj i Banatu (Kanjiža, Horgoš, Senta pa sve do Mokrina) ustupe Mađarskoj uz obavezu da tu primi još 200.000 Mađara iz Vojvodine, čime bi preostali deo bio etnički čistiji, ali ovakvi predlozi nisu razmatrani na ozbiljnijem državnom nivou. ${ }^{28}$

Sporno pitanje u Vojvodini, osim razgraničenja sa Mađarskom, bilo je i razgraničenje sa Hrvatskom. Ministarstvo za Hrvatsku u vladi DFJ tražilo je da se odlože izbori zakazani za 16. maj 1945, dok se ne završi razgraničavanje između Hrvatske i Vojvodine. Glavni NOO Vojvodine uvažio je hrvatski protest, pa je Baranja izuzeta iz sastava Vojvodine, dok je za područje u severozapadnoj Bačkoj i Sremu, 19. juna 1945, formirana komisija od predstavnika AVNOJ-a. Nacionalni odnosi između Srba i Hrvata u Vojvodini su bili pod uticajem događaja u Drugom svetskom ratu i naročito zategnuti na teritoriji Srema, a KPJ je nastojala da ih prevaziđe u skladu sa novom politikom bratstva i jedinstva. Međutim, ovaj veštački osećaj bratstva i jedinstva nije bio održiv, pa su jula 1945. izbile masovne demonstracije u Sremskoj Mitrovici protiv Srba, te je odlučeno da se status Vojvodine mora definisati što pre. To je i učinjeno 7. avgusta 1945. na Trećem zasedanju AVNOJ-a kada je odlučeno da se Vojvodina priključi Srbiji, a pitanje granica ostavljeno je Privremenoj narodnoj skupštini da ga reguliše posebnim zakonom. ${ }^{29}$ Pokrajinski komitet je stalno upozoravao da se u Vojvodini ne sprovode direktive KPJ i da se mora sprečiti ,velikosrpski šovinizam“, u prilog politike „bratstva i jedinstva“. Komunisti su srpske povratnike označavali kao „netrpeljive“ i ,šovinistički raspoložene“. ${ }^{30}$ U novoj Jugoslaviji nije smelo da bude mesta šovinizmu niti lokalnom patriotizmu, svi građani su morali prvenstveno da se osećaju kao Jugosloveni, a KPJ je smatrala da su sve razlike stvar prošlosti i da će ih socijalizam jednostavno izbrisati, što se pokazalo kao mit.

Blagoje Nešković je pitanje Vojvodine istakao kao posebno u referatu podnetom Narodnoj skupštini: „Vidimo da se danas pojedine nacionalne grupe u Vojvodini uglavnom drže onako, kako su se držale i pri oslobođenju Vojvodine, a delimično i onako kako su se držale pod okupacijom“. ${ }^{31} \mathrm{Na}$ početku je podsetio na saradnju sa okupatorom određenih nacionalnih grupa, misleći prvenstveno na Nemce, Hrvate i Mađare. Ta saradnja nije mogla biti olako zaboravljena ni u partijskom vrhu, ni među stanovništvom. Jedan od zadataka komunističke vlasti bio je da pokuša da izmiri nacionalne netrpeljivosti i uključi što više narodnosti u svoj pokret. Nešković je u svom govoru podvukao značaj Srba iz Vojvodine u razvoju komunističkog pokreta i njihov doprinos oslobođenju: „Doprinos naroda Vojvodine, a pogotovo Srba, Srema n. o. pokretu jeste

\footnotetext{
${ }^{27}$ В. Глишић, н. д., 91.

${ }^{28}$ Исто.

${ }^{29}$ Коста Николић, Србија у Титовој Југославији 1941-1980 (Београд: Завод за уџбенике, 2011), 194.

${ }^{30}$ Исто.

${ }^{31}$ IAB, 2157-10-5, Referat o političkom stanju u Srbiji, Vojvodini i Kosovu i Metohiji.
} 
ogroman. Takvo svoje držanje narod Vojvodine $i$ to još uvek narod Srema $i$ to Srba, nastavlja i dalje. Nema sumnje da su činjeni napori i da se čine u cilju aktiviziranja i drugih nacionalnih grupa, ali dosadašnji rezultati nisu zadovoljavajući. Ne bi smeli da se zanosimo uspesima postignutim u Vojvodini do te mere da ne vidimo stvarno postojanje nacionalnih frontova. Nema sumnje [...] da je fašistički okupator sav bes ugnjetavanih nacija pod bivšom Jugoslavijom umeo vešto da okrene protiv nedužnih Srba u Vojvodini. U nekoliko je razumljivo, iako ne uvek opravdano, nezadovoljstvo Srba za vreme okupacije prema drugim nacionalnim grupama“". 32

U ovom delu govora Nešković ukazuje na to da je bio svestan nepovoljne pozicije Srba u Vojvodini za vreme rata i terora koji su pretrpeli prvenstveno od strane okupatora, ali i pripadnika nemačke, mađarske i hrvatske nacionalne manjine koja je najvećim delom sarađivala i pomagala u tome. ${ }^{33}$ Govoreći o situaciji u Vojvodini, on je na momente kontradiktoran i stiče se utisak da je stalno u procepu. Kao Srbin saosećao je sa sudbinom Srba u Vojvodini tokom rata i bio je svestan zločina koji su nad njima počinjeni. Zbog toga je smatrao razumljivim njihovo nepoverenje i netrpeljivost prema ostalim nacionalnostima, i delimično opravdanim. Ipak, u skladu sa politikom nacionalnog pomirenja koju je KPJ sprovodila, on nije bio u mogućnosti da slobodno i otvoreno izrazi svoje nacionalno osećanje, jer je na taj način vrlo lako mogao biti optužen za širenje ,,velikosrpstva“. Kao komunista morao je da bude na pozicijama Partije, pa je već u sledećem pasusu istakao: „Nikako nije razumljivo niti opravdano da se danas i u rukovodstvima i u masovnim organizacijama partijskim i antifašističkim, a da ne govorimo o samim Srbima u Vojvodini, govori o Hrvatima kao celini i o Mađarima kao celini, koje se neprijateljski drže prema n. o. pokretu, i još je manje dozvoljeno pogrdno ocenjivanje pojedinih nacionalnih grupa u celini““ 34

Na Kongresu svih Slovena u Rumuniji od 21. aprila 1945. postavljeno je pitanje nacionalnih prava Slovena u Rumuniji, ali ono se odnosilo na demokratizaciju zemlje. Jugoslavija nije želela da postavlja teritorijalno pitanje u odnosu na Rumuniju niti da traži prisajedinjenje teritorija naseljenih slovenskim življem. ${ }^{35} \mathrm{O}$ odnosu prema vlaškom pitanju, koje je povezivano u to vreme sa Rumunijom, Blagoje Nešković kaže: „Po povratku Broza iz Rumunije odmah posle rata, Broz mi je rekao da je Ana Pauker pitala da li bi istočna Srbija mogla da se priključi Rumuniji jer su Vlasi koji tamo žive u stvari Rumuni. Broz im je rekao da oni o tome treba da razgovaraju sa Neškovićem. Kada mi je to Broz rekao, ja sam žestoko opsovao i rekao: 'Neka mi se samo obrate, reći ću ja njima kako treba'. Naravno da se nisu obratili jer im je Broz javio kako sam rea-

\footnotetext{
${ }^{32}$ Isto.

${ }^{33}$ Zločini na jugoslovenskim prostorima u Prvom i Drugom svetskom ratu, tom I, knjiga 1, priredili Slavko Vukčević, Danica Milenković, Anka Radovanović i Momčilo Todosijević (Beograd: Vojnoistorijski institut, 1993), 551; Goran Babić, Paor sa bajonetom, Zločin i kazna vojvođanskih folksdojčera (Beograd: Službeni glasnik 2012), 31-41; Ђорђе Н. Лопичић, прир., Немачки ратни злочини 1941-1945 (Београд: Музеј жртава геноцида, 2009).

${ }^{34} \mathrm{IAB}, 2157-10-5$.

${ }^{35}$ B. Petranović, Istorija Jugoslavije, III, 176.
} 
govao. Nakon Osnivačkog kongresa KP kada se postavilo pitanje Vlaha, organizovano je njihovo izjašnjavanje na kome su se oni izjasnili kao Srbi“ “. ${ }^{36}$

Odnosi prema Albaniji, pogotovo osetljivo pitanje Kosova i Metohije, bili su vrlo aktuelni posle rata. Između Privremene vlade Albanije i Nacionalnog komiteta oslobođenja Jugoslavije 20. februara 1945. u Beogradu potpisana su dva značajna ugovora: o vojnom savezu protiv Nemačke i o razmeni privrednih dobara. ${ }^{37}$ Sledeći korak bilo je priznavanje albanske vlade što je učinila Privremena vlada DFJ 28. aprila 1945, čime je potvrđen proces njihovog zbližavanja, a i Jugoslavija se zalagala da se Albaniji isplate reparacije i prizna status savezničke zemlje. Jugoslavija je podržala Albaniju u grčkim pretenzijama na Epir. $^{38}$ Odnos između dve zemlje je učvršćen i ekonomskim ugovorom, a Nešković je pozitivno ocenio ovakvo približavanje: „Ovaj ugovor je ekonomskog karaktera i sa ranijim ugovorom o međusobnoj pomoći čini jednu celinu. Njegovim ostvarenjem ubrzaće se ekonomski razvitak obeju zemalja. Nikakve sumnje nema da će naša savezna vlada na čelu s drugom Titom odgovoriti $u$ potpunosti svim obavezama koje proističu iz ugovora" 39

KPJ je tražila načine da pridobije što veći broj Albanaca za svoju politiku. Na prostoru Kosmeta 1945. godine bilo je oko 1000 članova Partije, od čega oko 300 Albanaca. Ovaj broj se naredne godine povećao pet puta u odnosu na srpsko i albansko stanovništvo. ${ }^{40} \mathrm{KPJ}$ je naročito nastojala da pridobije Albance za ulazak u Partiju, pošto je njihov broj bio gotovo četiri puta manji u odnosu na broj Srba članova Partije. Na terenu je nastojala da manje kompromitovane odmetnike vrati normalnom životu i da ih inkorporira u organe lokalne vlasti. ${ }^{41}$ Ovakva politika, međutim, nije dala povoljne rezultate na duže staze i nije suzbila nacionalizam niti težnju Albanije da pripoji ovu oblast. Za pitanje Kosova i Metohije (KiM), Albanija je bila živo zainteresovana bez obzira na to što su dve zemlje popravile odnose u posleratnom periodu. ${ }^{42}$

Država je nastojala da ulaže u zaostalu kulturu i privredu na Kosovu i Metohiji. Petogodišnjim planom je predviđeno ulaganje $u$ industrijalizaciju i ovih oblasti, za šta se zalagao i Blagoje Nešković: „Imamo zadatak da sprovedemo princip ravnopravnosti, na nama je da taj princip ostvarimo na privrednom polju i da omogućimo Kosovu i Metohiji da podigne industriju. U tom pogledu naša Vlada i ministarstva čine napore da se raspoloživa industrija koja postoji, a koja nije neophodna na mestu gde se nalazi prenese na Kosmet. ${ }^{\text {‘43 }}$

\footnotetext{
${ }^{36}$ В. Глишић, н. д., 94.

37 Александар Животић, Југославија, Албанија и велике силе 1945-1961 (Београд: Архипелаг, Институт за новију историју Србије, 2011), 119-120.

38 Исто, 189.

${ }^{39}$ IAB, 2157-10-2, Govor Blagoja Neškovića povodom potpisivanja ugovora između naše zemlje i Narodne republike Albanije o usklađivanju privrednih planova, o carinskoj uniji i izjednačenju valute.

${ }^{40}$ К. Николић, Србија у Титовој Југославији, 269.

${ }^{41}$ Branko Petranović, Balkanska federacija 1943-1948 (Beograd: Zaslon, 1991), 103.

42 Б. Петрановић, Југословенско искуство српске националне интеграције, 97.

43 AS, G-18, NRS, Prepis govora predsednika vlade Srbije dr Blagoja Neškovića.
} 
Kritikujući odnos bivšeg režima, koji je navodno posebno bio uperen protiv Albanaca na Kosovu i Metohiji, Blagoje Nešković je bio neobjektivan, ali je u ovom govoru nastojao da se drži zvanične linije Partije.

Ovo je potvrdio i izveštaj Fadilja Hodže upućen vladi na njen zahtev: „Pristupanjem planskoj privredi u toku 1947. utrošeno je na ekonomsko podizanje Oblasti 413.321.000 dinara, što iznosi veću sumu novca nego što je za te svrhe utrošila stara Jugoslavija za 23 godine svoje vladavine. U toku 1948. godine u našoj Oblasti predviđaju se investicije od 554.365.050 dinara. Kako investicije iz 1947. tako i iz ove godine namenjene su podizanju industrije, poboljšavanju stambenih prilika, podizanju škola, zdravstvenih i kulturnih ustanova, uređenju gradova i naselja, podizanju standarda života radnog naroda ovog kraja. Danas u našoj Oblasti razvija se široka izdavačka delatnost na šiptarskom jeziku“. ${ }^{4}$

Za privredni razvoj bilo je vezano i drugo značajno pitanje: agrarna reforma i kolonizacija na Kosovu i Metohiji. Srpskim i crnogorskim kolonistima je 6. marta 1944. zvanično zabranjeno da se vrate na KiM, a umesto toga bili su usmereni na Vojvodinu. Nasuprot tome dozvoljen je ostanak onih Albanaca koji su se doselili na KiM u toku rata, što je rezultiralo pražnjenjem od srpskog i crnogorskog stanovništva i povećanjem populacije muslimanskog stanovništva. ${ }^{45}$ Posle donošenja Zakona o reviziji dodeljivanja zemlje kolonistima i agrarnim interesentima u Makedoniji i Kosovsko-metohijskoj oblasti započeo je rad mešovitih komisija koja su nastojale da onemoguće povratak ranije nastanjenih lica na ovim teritorijama. ${ }^{46}$ Ovako sprovedena agrarna reforma je omogućila da se albanskim seljacima podeli zemlja koja je do tada pripadala srpskim veleposednicima i crkvi. ${ }^{47}$ Pitanje agrarne reforme istakao je i Blagoje Nešković u svom govoru: „Krupan zadatak koji je stajao pred našim narodnim vlastima bio je izvođenje agrarne reforme i kolonizacije. Do sada je po liniji spoljne kolonizacije naseljeno sa teritorije naše republike 11.492 kolonističke porodice. U toku preseljenja još oko 600 porodica sa teritorije uže Srbije i Autonomne oblasti Kosova i Metohije. $\mathrm{Na}$ teritoriji Autonomne pokrajine Vojvodine eksproprisano je agrarnom reformom oko 200.000 hektara zemlje, a na teritoriji uže Srbije i Autonomne oblasti Kosova i Metohije 68.700 hektara. Na teritoriji Autonomne pokrajine Vojvodine zemlju je dobilo oko 88.000 porodica, a na teritoriji uže Srbije i Autonomne oblasti Kosova i Metohije oko 37.000 porodica“" 48

O stanju na Kosovu i Metohiji Nešković u svom referatu navodi: „Osnovno pitanje na Kosovu i Metohiji jeste pitanje zemlje. Agrarno pitanje se rešavalo tokom vremena, i pre i tokom ovog rata, na parče, nepotpuno i uvek na štetu seljaštva. Zemlja je otimana od Šiptara i deljena bilo naseljenicima, bilo slugama raznih predratnih režima. [...] Nesumnjivo da je važno pitanje verske

\footnotetext{
${ }^{44}$ IAB, 2157-10-2, Izveštaj Fadilja Hodže upućen predstavništvu vlade NRS.

${ }^{45}$ Б. Петрановић, Југословенско искуство српске наџионалне интеграције, 98.

${ }^{46}$ А. Животић, н. д., 122-123.

${ }^{47}$ Бранко Петровић, Југославија на размеђу 1945-1950 (Подгорица: Црногорска академија наука и умјетности, 1998), 315.

${ }^{48}$ Исто, 38 .
} 
tolerancije, jezika, škola, učestvovanja u vlasti i administraciji i ostalih nacionalnih prava i da će sve to uticati na odnos šiptarskih masa prema n. o. pokretu, ali suština pitanja jeste pitanje zemlje“". ${ }^{49}$

Blagoje Nešković je akcenat stavio na pitanje zemlje koje je označio kao ključno pitanje u odnosima između Srba i Albanaca - a ne na nacionalno, koje je u stvarnosti bilo goruće - jer je tako bilo bezbolnije. Netačna je njegova konstatacija da je ,zemlja pre rata otimana od Šiptara“ i da su oni bili diskriminisani, što ih je izazvalo da pristupe ,velikošiptarskoj reakciji“. U zvaničnim obraćanjima on je zastupao liniju Partije, koja je nastojala da Albancima oprosti učešće u Drugom svetskom ratu i pripiše ga njihovim zabludama. ${ }^{50}$

Odnos Blagoja Neškovića prema nacionalnim odnosima na Kosovu i Metohiji naveden je kao jedan od razloga za njegovo isključivanje iz KPJ 1952. godine. Đoko Pajković, koji se nalazio na čelu Oblasnog komiteta, dao je 9. septembra 1952. izjavu u kojoj je napao Blagoja Neškovića za nerazumevanje prilika na KiM: „Kao posledicu slabih međusobnih odnosa među nacionalnostima na Kosovu i Metohiji, kao i zločinačke politike okupatora, mi smo nakon rata imali u oblasti oko 25.000 imovinskih sporova i oko 10.000 sporova oko popaljenih i porušenih kuća, između Šiptara i ostalih. Stav Oblasnog komiteta po ovom pitanju bio je da se sporovi rešavaju sporazumno, poravnanjem itd. Zbog toga su bile stvorene zajedničke komisije (Šiptari i drugi) po opštinama sa zadatkom da ove stvari rešavaju. To je sve bilo onda kada na većem dijelu teritorije oblasti nijesu postojale partijske organizacije, te je za rešenje ovog pitanja bilo potrebno više vremena. Blagoje Nešković je sa ovakvim radom bio nezadovoljan, otpužujući nas u Obl. komitetu da ne radimo, da se plašimo Šiptara, ističući da treba imati oštriji kurs prema Šiptarima, a ako oni protiv toga reaguju onda im treba reći 'da ćemo ih iseliti'“. 51

Stavovi Blagoja Neškovića prema Albancima su se bitno razlikovali u njegovim javnim govorima u odnosu na izjave date saradnicima. Dok se u javnim nastupima držao linije Partije, u privatnim razgovorima njegovi stavovi su bili u skladu sa njegovim nacionalnim osećanjem: „Neposredno pred izbore 1945. kada je Obl. Komit. na osnovu interesovanja koje je postojalo u masama pitao Blagoja Neškovića kako će se riješiti pitanje Kosova i Metohije u novoj državi on je vjerovatno zbog stava prema Šiptarima rekao da će biti 'okrug u okviru Republike', ignorišući naša mišljenje o potrebi autonomije nacionalističkim, neznalačkim itd. Ponavljajući i ovog puta stav da su Šiptari teški grešnici iz rata, da im je zbog toga i to mnogo, kao i da svako izraženo nezadovoljstvo može povlačiti njihovo iseljenje. Mislim da ne treba da posebno ističem koliko nas je iznenadio i začudio ovakav stav part. rukovodstva“". ${ }^{2}$

Premda je izjava Đoke Pajkovića bila subjektivna i imala cilj da što više ocrni Blagoja Neškovića pred komisijom formiranom povodom njegovog sluča-

\footnotetext{
${ }^{49}$ IAB, 2157-10-7, Referat o političkom stanju u Srbiji, Vojvodini i Kosovu i Metohiji.

${ }^{50}$ Isto.

${ }^{51}$ Privatna arhiva Nebojše Neškovića, Dosije o Blagoju Neškoviću, Izjava Đoke Pajkovića, 1.

${ }^{52}$ Isto.
} 
ja, ipak on sam nikada nije demantovao ove optužbe. Naprotiv, kasnije je tvrdio da se nije slagao sa nacionalnom politikom vođenom prema Albancima. Kako je posle rata ostalo nerešeno pitanje šta raditi sa albanskim porodicama koje nisu uspele da dođu do zemlje, a doselile su se na Kosovo i Metohiju, jugoslovenska strana je nameravala da ih vrati u Albaniju, što je na kraju i ostvareno za deo njih. Imajući i to u vidu, možemo da razumemo zašto Nešković pominje mogućnost iseljavanja. On je podržavao zvaničan stav vlade prema KiM i bio je protiv priključenja ove oblasti Albaniji, čemu je Albanija težila u posleratnom periodu. „Posle rata se u našem partijskom vrhu planirala federacija između Jugoslavije, Bugarske i Albanije. Tada me je Đilas u ime Broza pitao da li bih pristao da se Metohija priključi Albaniji, a da se Crna Gora priključi Srbiji. Ja sam to odbio“. 53

Đoko Pajković kritikuje i Neškovićevo ponašanje u politici otkupa na teritoriji KiM 1947. godine. Naime, nedostatak katastarskih podataka o tačnoj površini zemlje koje su držali seljaci predstavljao je problem prilikom određivanja otkupnih kvota. Zbog sumnji u ispravnost prijava seljaka Ministarstvo trgovine je donelo odluku da se površine povećaju za 20\% i tako uzima otkup. Pajković navodi da je odmah ukazao Neškoviću na neispravnost takve odluke, ali se on oglušio o tu sugestiju. Kasnije je ministarstvo povuklo svoju odluku i smanjilo zaduženja za iznose koliko su povećane površine zemlje jer se pokazalo da je stanovništvo previše opterećeno. Prema njegovim rečima, B. Nešković je navodno i tada insistirao da se zadrži povećanje od $20 \%$ prema kojem su računate otkupne kvote i tako previše opterete seljaci. ${ }^{54}$

$\mathrm{Na}$ osnovu istorijskih izvora znamo da je Nešković kritikovan zbog otkupne politike u Vojvodini zato što je, prema merilima Partije, bio previše blag $\mathrm{u}$ utvrđivanju otkupnih kvota. Nezadovoljan politikom srpskog rukovodstava, Josip Broz Tito je na sednici Politbiroa od 4. marta 1947. kritikovao CK KP Srbije, posebno sekretara Blagoja Neškovića, a zatim i članove Milentija Popovića, Jovana Veselinova i Petra Stambolića optužujući ih za sektaštvo i oportunizam, svojevoljno smanjivanje otkupnih količina, nepoštovanje odluke $\mathrm{CK}$, otpor prema liniji Partije, izazivanje problema u snabdevanju i nesnalaženje na suzbijanju seljačkog otpora u Vojvodini. ${ }^{55}$ Blagoje Nešković je kao najodgovornije lice najviše kritikovan za neuspeh otkupa u Srbiji, ali za razliku od ostalih nije hteo da bespogovorno prihvati kritike što nije bila uobičajena niti poželjna reakcija u sistemu KPJ. Sednica je pokazala da srbijansko rukovodstvo nije bilo kompaktno u odbrani svojih stavova. Oštra kritika kojoj je Blagoje Nešković bio izložen na ovom sastanku, kao i ceo srpski kadar, može se uzeti kao početak politike Josipa Broza usmerene na slabljenje Srbije i to baš putem kritike i odstranjivanja najsposobnijih kadrova sa političke scene, Blagoja Neškovića, a kasnije i Aleksandra Rankovića. ${ }^{56}$

\footnotetext{
${ }^{53}$ IAB, 2157-10-1, Zahtev za rehabilitaciju, K-10, 1.

${ }^{54}$ Privatna arhiva Nebojše Neškovića, Dosije o Blagoju Neškoviću, Izjava Đoke Pajkovića, 1.

${ }^{55}$ Arhiv Jugoslavije (AJ), fond 507, CK SKJ, Politbiro III/24, Sastanak Politbiroa CK KPJ sa rukovodstvom CK KP Srbije 4. marta 1947; Ivana Dobrivojević, Selo i grad: transformacija agrarnog društva Srbije 1945-1955 (Beograd: Institut za savremenu istoriju, 2013), 89.

56 Јелена Попов, Драма на војвођанском селу: (1945-1952):обавезни откуп пољопривредних производа (Нови Сад: Платонеум, 2002), 229.
} 
To je samo jedno od mogućih tumačenja, ali ono što je sigurno jeste da je kritika u Politbirou za posledicu imala dodatno pooštravanje mera prema „kulacima“, ali i prema nižem partijskom kadru. Nastojeći da se dokaže kao „dobar komunista“, svestan težine optužbi da odstupa od partijske linije, Blagoje Nešković je pojačao pritisak da bi se zadate norme ostvarile. Za teritoriju Kosova i Metohije nemamo podatak da je Partija bila nezadovoljna njegovim radom, a državi je svakako išlo u prilog da otkupne kvote budu što veće. Vrlo je verovatno da je posle pretrpljene kritike zbog rezultata otkupa u Vojvodini Nešković pooštrio odnos prema otkupu u celoj državi, pa otuda i njegovo uporno insistiranje da se zadrži povećano obračunavanje za $20 \%$ površine.

Bez obzira što je u NR Srbiji pooštrio otkupnu politiku Blagoje Nešković je bio jedini koji se po pitanju otkupa suprotstavio „drugovima“ iz Hrvatske i Slovenije na Trećem plenumu CK KPJ (održanom 29-30. decembra 1949) insistirajući na ravnomernijoj raspodeli otkupnih količina među republikama. Suprotstavio se stavu Edvarda Kardelja i Vladimira Bakarića da će pritisci na seljake u Hrvatskoj izazvati političke probleme u toj republici i da je Hrvatska otkupom već previše opterećena: „Mi se, rekao je, protiv te pojave moramo boriti političkim radom, moramo postaviti tu stvar kao političku i voditi klasnu borbu. A mi često fatalistički posmatramo izvesne objektivne, ekonomske i društvene zakone u toj klasnoj borbi. ${ }^{\text {"57 }}$ Briga o fondovima nije samo stvar savezne vlade i Centralnog komiteta, ocenio je Nešković, insistirajući da se i pojedinačno u republikama predlože i sprovedu takve mere koje mogu da doprinesu povećanju prinosa i obezbeđivanju od elementarnih nepogoda. ${ }^{58}$ Vladimir Bakarić, sekretar CK KPH, tvrdio je da je u Hrvatskoj postojao problem sa setvom, ali je insistirao na tome da je plan za Hrvatsku bio preveliki. Bakarića je podržao Edvard Kardelj, koji se složio da je plan za Hrvatsku preveliki i istakao kako je zajedno sa njim ,upoređivao cifre plana otkupa za Hrvatsku i Srbiju. Prema onim ciframa na papiru, koje bi morale da budu tačne, plan otkupa za Hrvatsku je bio preveliki. Ali taj plan nije u srazmeri sa planom za Srbiju, koji je veliki; on nije nikako suviše veliki, nego pre obrnuto.“59 Prema njegovom shvatanju plan za Srbiju je mogao biti i veći. Blagoje Nešković, iako je smatrao da sveukupni plan može biti veći, jedini se direktno suprotstavio stanovištu rukovodilaca iz Hrvatske i Slovenije. Činjenica je da je Srbija ekonomskim planom otkupa bila najviše pogođena, od nje se očekivalo da se najviše žrtvuje u ime „bratstva i jedinstva“. Politički gledano, iz njenog državnog i partijskog aparata uklanjani su postepeno oni koji su pokušavali da zaštite makar u najblažoj formi srpske nacionalne interese. Držanje Blagoja Neškovića na Trećem plenumu samo je još jednom potvrdilo da on nije u potpunosti bio spreman da dokazuje tzv. internacionalizam na štetu ličnog nacionalnog osećanja, što će ga tri godine kasnije koštati partijske karijere i članstva u KPJ.

\footnotetext{
57 Sednice Centralnog komiteta KPJ: 1948-1952, priredili Branko Petranović, Ranko Končar i Radovan Radonjić (Beograd: Komunist, 1985), 456-457.

${ }^{58}$ Isto.

${ }^{59}$ Isto, 454.
} 
Slučaj Blagoja Neškovića je zvanično pokrenut na sednici Politbiroa održanoj uoči Šestog kongresa KP Srbije 29. septembra 1952. godine. Sednici su prisustvovali Dušan Petrović Šane, Spasenija Cana Babović, Jovan Veselinov, Mitra Mitrović, Slobodan Penezić Krcun, Voja Leković, Rista Antunović, Miloš Minić i Dragi Stamenković. Kada je trebalo da bude isključen iz Partije etiketiran je i da je bio netrpeljiv prema Slovencima i Crnogorcima i da je sumnjao da Boris Kidrič i Franc Leskošek rade na štetu NR Srbije, a u korist Narodne Republike Slovenije. To mu je uzeto kao težak greh u odnosu na politiku bratstva i jedinstva, u kojoj se očekivalo da Srbija treba dobrovoljno da se najviše založi za njegovo očuvanje. ${ }^{60}$

U optužnici protiv Blagoja Neškovića navedeno je između ostalog: „B. Nešković se duboko ne slaže sa politikom naše Partije u nacionalnom pitanju i stalno se odnosi prema njoj i prikazuje je kao da je ona na štetu srpskog naroda. Svoj velikosrpski šovinizam on je ispoljio bezbroj puta, i to u najrazličitijoj formi, čak i na takvim, ne samo za komunistu, nego i za običnog građanina beznačajnim sitnicama, kao što su na primer, natpisi latinicom u Beogradu. “61 Ovaj deo optužbe je bio najozbiljniji i otkrivao je suštinske razloge za smenjivanje Blagoja Neškovića. Ispoljavanje nacionalnog sentimenta uzimano je kao težak greh, naročito ako su u pitanju bile optužbe za ,velikosrpski šovinizam“. O tome koliko je strah od njega bio ukorenjen i koliko je bilo važno pokazati težnju za ravnopravnošću, govori i činjenica da se nije smelo slobodno istaći pravo na davanje prednosti sopstvenom pismu i da su smatrane sitnicom stvari „kao što su na primer, natpisi latinicom u Beogradu“. Ako se korišćenja pisma i jezika smatra temeljima na kojima se gradi nacionalni identitet jednog naroda, ne iznenađuje što se Blagoje Nešković bunio protiv upotrebe latiničnih naziva i nametanja latinice Srbima. U javnim nastupima Blagoje Nešković se držao linije Partije jer drugačije nije ni smeo da postupa, ali lično nikada nije zaboravio da je Srbin pa nije ni bio u potpunosti saglasan sa nacionalnom politikom koju je vodila KPJ.

\section{Zaključak}

Srbija kao najveća i najjača država u jugoslovenskoj federaciji - koja je ranije vodila hegemonističku politiku, netolerantnu prema drugim narodima, $u$ kojoj je tokom rata bio aktivan ,četnički šovinistički pokret" - morala je sada da pokaže da se u potpunosti odrekla tih ideja i da se iskupi za učinjene nepravde. Slogan o ,velikosrpskom hegemonizmu“ pretvorio se u trajnu hipoteku koji je nosila Srbija, a srpski komunisti raspoznavali su se po borbi protiv vlastitog šovinizma i hegemonizma. Strah od širenja „,velikosrpstva“, majorizacije Srba, isticao se kao najveća politička opasnost, pa su srpski nacionalni problemi vezani za rat ostali nerešeni pošto bi pojedinac koji bi se na njih vratio lako mogao

\footnotetext{
${ }^{60}$ В. Глишић, н. д., 177.

${ }^{61}$ Privatna arhiva Nebojše Neškovića, Dosije Blagoja Neškovića, Pismo Politbiroa CK KPS Politbirou CK KPJ od 20. septembra 1952. godine, 2.
} 
biti optužen za „velikosrpstvo i šovinizam“, što se nije opraštalo. Na svaki pokušaj ili pomisao srpskog objedinjavanja gledano je kao na kontrarevolucionarni čin, dokaz postojanja velikosrpskog šovinizma koji preti temeljima nove Jugoslavije. Blagoje Nešković, pak, kao srpski kadar u okviru nove komunističke vlasti, nikada nije bio u stanju da prihvati politiku Josipa Broza Tita o slabljenju Srbije. Iako je u zvaničnim izveštajima morao da podrži politiku nacionalnog pomirenja, nerado je činio ustupke i po pitanju razgraničenja sa susednim državama, a od svojih kolega i saboraca je zbog prosrpskih stavova bio viđen kao „Velikosrbin“ i ,šovinista“ što je bilo u suprotnosti sa jugoslovenskom politikom. Njegovi predlozi za rešavanje nacionalnog pitanja u državi (odnos prema Albancima, stav prema Mađarima u Vojvodini itd.), izgledali su veoma represivni u odnosu na politički kurs. Kao rođeni Šumadinac, koji je svoje školovanje i mladost proveo u Srbiji, u kojoj je boravio tokom najvećeg dela rata, nije bio spreman da se odrekne nacionalnog osećanja u onoj meri u kojoj je politički vrh to zahtevao od njega. To je neminovno moralo dovesti do sukoba sa političkim saradnicima i sa samim Josipom Brozom, koji je sprovodio ideju slabljenje Srbije na račun jačanja Jugoslavije. Pozicija Blagoja Neškovića u Srbiji povlačila je sa sobom veliku odgovornost. Kao srpski kadar bio je pod budnim okom Josipa Broza koji je gajio izvesno podozrenje prema Srbiji i kome nisu odgovarali jaki i neposlušni ljudi na njenom čelu. Na drugom kraju su bila njegova lična uverenja i osećanja koje nije bio u stanju da potisne u potpunosti, što je doprinelo uklanjanju sa političkih pozicija kao krajnjem ishodu. 


\section{REFERENCE}

- Babić, Goran. Paor sa bajonetom, Zločin i kazna vojvođanskih folksdojčera. Beograd: Službeni glasnik 2012.

- Dimitrijević Bojan, i Dragan Bogetić. Tršćanska kriza 1945-1954. Beograd: Institut za savremenu istoriju, 2009.

- Dobrivojević, Ivana. Selo i grad: transformacija agrarnog društva Srbije 1945-1955. Beograd: Institut za savremenu istoriju, 2013.

- Glišić, Venceslav. Dosije o Blagoju Neškoviću: prilozi za biografiju. Beograd: Službeni glasnik, 2011.

- Izvori za istoriju SKJ. Dokumenti centralnih organa KPJ. NOR i revolucija 1941-1945, knjige 18 i 19. Priredio Milovan Dželebdžić. Beograd: Izdavački centar komunist, 1986.

- Lopičić, N. Đorđe, prir. Nemački ratni zločini 1941-1945. Beograd: Muzej žrtava genocida, 2009.

- Nikolić, Kosta. Srbija u Titovoj Jugoslaviji (1941-1980). Beograd: Zavod za udžbenike, 2011.

- Nikolić, Kosta. Mit o partizanskom jugoslovenstvu. Beograd: Zavod za udžbenike, 2015.

- Petranović, Branko. Istorija Jugoslavije 1918-1988, I-III. Beograd: Nolit, 1988.

- Petranović, Branko. Balkanska federacija 1943-1948. Beograd: Zaslon, 1991.

- Petranović, Branko. Jugoslovensko iskustvo srpske nacionalne integracije. Beograd: Službeni list SRJ, 1993.

- Petranović, Branko. Jugoslavija na razmeđu (1945-1950). Podgorica: Crnogorska akademija nauka i umjetnosti, 1998.

- Piljević, Đorđe O. „Savetovanje Politbiroa CK KPJ na Visu i stvaranje KP Srbije“. U: Osnivački kongres Komunističke partije Srbije: zbornik radova. Urednik Aleksandar Kasaš, 41-44. Beograd: Zavod za udžbenike i nastavna sredstva, 1988.

- Popov, Jelena. Drama na vojvođanskom selu: (1945-1952): obavezni otkup poljoprivrednih proizvoda. Novi Sad: Platoneum, 2002.

- Sednice Centralnog komiteta KPJ: (1948-1952). Priredili Branko Petranović, Ranko Končar i Radovan Radonjić. Beograd: Komunist, 1985.

- Zločini na jugoslovenskim prostorima u Prvom i Drugom svetskom ratu, tom I, knjiga 1. Priredili Slavko Vukčević, Danica Milenković, Anka Radovanović i Momčilo Todosijević. Beograd: Vojnoistorijski institut, 1993.

- Životić, Aleksandar. Jugoslavija, Albanija i velike sile (1945-1961). Beograd: Arhipelag, Institut za noviju istoriju Srbije, 2011. 
ENA MIRKOVIĆ, PhD, Research Assistant

Institute for Serbian Culture - Priština/Leposavić

Leposavić, Republic of Serbia

ena04111986@gmail.com

\author{
BLAGOJE NEŠKOVIĆ'S ATTITUDE \\ TOWARDS THE NATIONAL QUESTION 1944-1952
}

\begin{abstract}
Summary
This paper analyses the political views on the national question of Blagoje Nešković, prominent personality of Serbian Communist movement until 1952. During World War II he was elected to the post of secretary of the Provincial Committee of the Communist Party of Yugoslavia for Serbia, after the liberation he was the secretary of the Central Committee of the Communist Party of Serbia and the Serbian prime minister until 1948. In 1952 he became Deputy Prime Minister of the Federal Republic of Yugoslavia, but soon he was accused for opportunistic policy implementation and cooperation with the Cominform, he was forced to resign all party posts and expelled from the Central Committee of Yugoslavia. His case raises many serious questions to explore, such as the freedom of expression of national positions in the new communist Yugoslavia and the position of the Serbian communist elite in relation to the communist elite of Yugoslavia. The Serbian elite were the least compact and the weakest in the new country and owned the highest mortgage from the war and the maximum load as the elite of the largest nation that would later be named the hegemonic. KPJ showed its readiness in order to deal with all those who were able to question the correctness of its policy. Blagoje Nešković was not a suitable person to support the national policy of weakening Serbia at the expense of strengthening of Yugoslavia. His dissent in national politics, disapproval of the purchase of policy implementation, representation of Serbian national interests and the growing political influence and disobedience led to conflict with Josip Broz Tito, and other political officials, whose policy was exactly the opposite.
\end{abstract}

KEYWORDS: Blagoje Nešković, the national question, Serbia, Communist Party of Yugoslavia 